menneskelig modell. Lauvengs arbeider er også et uttrykk for dette. Arbeidsmaur med gipset hjerte kan leses som en konkret veileder i attføringsprosessen, men representerer også en grunnbok i holdninger til psykisk lidelse.

Den er så sentral og så godt skrevet at den egner seg for alle med interesse for psykisk lidelse. Målgruppen er i utgangspunktet arbeidstakere og deres omgivelser $\mathrm{i}$ arbeidslivet, fra kolleger til NAV-ansatte. Denne utgivelsen er selvfølgelig nyttig og tankevekkende også for spesialisthelsetjenesten.

\section{Vrøvl om besettelse og ingenting om avhengighet}

\section{Dysthe P.}

\section{Besettelsen}

En historie om avhengighet. 219 s. Oslo Cappelen Damm, 2008. Pris NOK 329

ISBN-978-82-04-14287-0

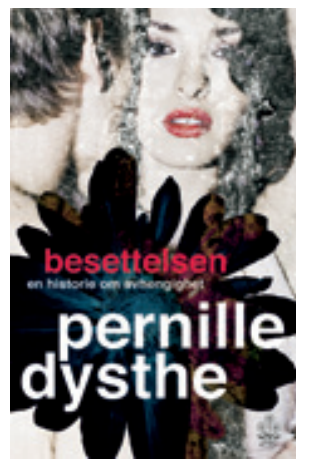

Av og til angrer man på at man har sagt ja til å skrive en anmeldelse. Man bør jo yte boken rettferdighet ved å lese den, ikke bare skumme her og der, men lese den fra perm til perm. Det er jo flaut hvis man uttaler seg negativt om en utgivelse som viser seg å ha et poeng - et punkt som snudde det hele fra uforklarlig smørje til poengtert mening. Denne anmeldelsen angret jeg på etter å ha lest vaskeseddelen. Og ikke på noe tidspunkt, i løpet av de 217,5 påfølgende sidene, lot jeg være å angre. Jeg angret fra perm til perm.

Det kom ikke noe poeng. Ingenting snudde dette. Ingenting brakte dette opp fra et flaut lavmål. Her er det bare et enormt ordgyteri om trivialiteter og uinteressante ting. Og verre enn det - nokså alvorlige ting, ting som betyr noe for folk, blant annet relasjoner og sex, blir gjort trivielt og uinteressant. Det gjøres gjennom å slenge ut tabuord og banale frekkaserier ustanselig. Besettelsen skal angivelig handle om avhengighet av Internett-sjekking. Tro meg - den handler ikke om noe som kan minne om avhengighet engang. Kan man bli avhengig av Internettsjekking? Her får vi ikke engang reminisenser av et svar. «Treffsikkert og på hudløst og humoristisk vis skildres menneskelige [...] mutasjoner anno 2008. [...] Nettsjekking blir ikke det samme etter dette,» står det på vaskeseddelen. Dette skulle illustrere hvilket sludder vi snakker om. Styr unna!

\section{Jørgen G. Bramness}

Senter for rus og avhengighetsforskning (SERAF) Universitetet i Oslo

\section{Men sykdommene mine får du aldri}

Hofmann B.

Hva er sykdom?

205 s, tab, ill. Oslo: Gyldendal Akademisk, 2008. Pris NOK 265

ISBN 978-82-05-35938-3

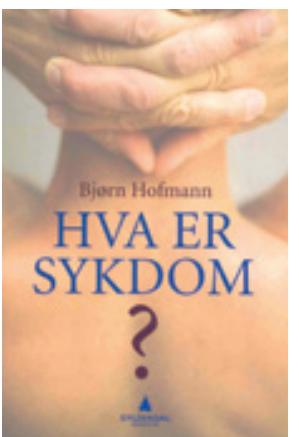

Bjørn Hofmann har skrevet en god bok om et umulig spørsmål: Hva er sykdom? I motsetning til helsebegrepet, som ganske ofte blir gjenstand for utførlige begrepsmessige utlegninger, blir sykdomsbegrepet sjelden drøftet på samme

måte. Til tross for at det, som Hofmann påpeker, står helt i sentrum av den medisinske praksis.

Teksten er en kontinuerlig problematisering av sykdomsbegrepet. Hva er det som kjennetegner en sykdom? Skal sykdom forstås som en ting i naturen, som et begrep eller som en sosial konstruksjon? Defineres den av sine årsaker, som en blanding av tegn og symptomer eller som forstyrret balanse? Eller er sykdom å forstå som avvik fra en norm? Kan verdi og fakta skilles når vi snakker om begrepet sykdom? Det er ganske mange fine og systematiske diskusjoner av disse spørsmålene, som hittil har vært lite fremme i den norske medisinske samtalen. Men hvem er teksten skrevet for?

Forordet tar en obligatorisk runde til målgruppen - som er medisinstudenter og mastergradstudenter innen ulike helsefag. Hofmann mener at sykdomsbegrepet er relevant for all medisinsk praksis. Til det formål har han og forlaget laget en bruksbok - uten noteapparat og med mange eksempler. Eksemplene er stort sett gode, med noen unntak (hvorfor kunne ikke forlaget spandert en medisinsk korrekturleser): Dendritt er ikke en sykdom (s. 9), men en anatomisk struktur, og man har ikke sluttet å gjøre angiografi ved spørsmål om myokardiskemi (s. 152).

Men hvor vellykket er ambisjonen om «å vise hvor relevant filosofien er for forståelse og utøvelse av helsefag»? De fleste medisinere er pragmatikere - og forholder seg ikke til slike filosofiske spørsmål. Deres sykdomsbegrep er intimt forbundet med kasus i praksis, og det er vanskelig å la en abstrakt diskusjon bli relevant for denne praksisen. Som Hofmann selv sier det: «Helsefaglig kunnskap er knyttet til handling: Vi vil vite for å hjelpe.» $\mathrm{Og} H v a$ er sykdom? gir ikke kunnskap til å hjelpe i hvert fall ikke umiddelbart. Men for den som vil se sitt fag i en større sammenheng, få et perspektiv på det de gjør, er den helt avgjørende. Jeg tror denne utgivelsen derfor først og fremst vil være av interesse for dem som i utgangspunktet er opptatt av eller arbeider med relaterte problemstillinger. For dem blir mangelen på noteapparat og eksplisitt diskusjon med den eksisterende litteratur utilfredsstillende - en mer inngående posisjonering ville ha gjort argumentasjonen klarere. I stedet omtaler Hofmann sin posisjon ved hjelp av termer som «vi» og «oss» - uten at det blir klart hvem det er (noen ganger er det «vi helsepersonell», andre ganger «vi forskerkollegium», dvs. Bjørn Hofmann selv).

På den annen side: For den interesserte leser finnes det her rikelig av stoff man kan begynne med hvis man ønsker å vite mer om hva «sykdom» er, og den utførlige litteraturlisten gir henvisning til videre studier. Alt $i$ alt er dette en utgivelse vi trengte i Norge, og forfatteren har gjort et imponerende stykke arbeid ved å vise hvordan sykdomsbegrepet unndrar seg all definisjon. Snarere enn å vise hvor relevant begrepet er i praksis, viser han hvor umulig det er å snakke om «sykdom» som noe enhetlig håndterbart. Som han selv sier: «Problemstillingens relevans avhenger av hvilket perspektiv man har.» Etter dette kan ingen med hånden på hjertet si at de vet hva sykdom er!

\section{Anne Kveim Lie}

Berlin

\section{Ellisif Wessel - myter og menneske}

Wikan S.

Ellisif Wessel

En biografi. 360 s, ill. Oslo: Pax, 2008.

Pris NOK 398

ISBN 978-82-530-3141-5

Den eksentriske Ellisif Wessel

(1866-1949) er antakelig norgeshistoriens mest berømte doktorfrue - kjent for den hun var og det hun gjorde, men også gjennom utallige myter og historier. For venstresiden i norsk politikk er hun et ikon. Blant fotografer har hun en etablert posisjon som folkelivsskildrer. Hennes tekster og dikt kan fortsatt leses med utbytte. Kombinasjonen av personlighet, tid, sted og til- 
feldigheter skapte en kvinneskikkelse som det er vanskelig å bli klok på.

Legedatteren Ellisif Rannveig Müller var sendt til Kristiania for å få en passende skolegang som basis for et fremtidig liv i samfunnets øvre sirkler. Der traff hun fetteren Andreas Bredal Wessel (1858-1940). Da han var ferdig med sin legeeksamen i 1885, giftet de seg og dro til Kirkenes, hvor de forble livet ut.

Knapt 20 år gammel kom Ellisif Wessel til et samfunn som både var temmelig fremmed og som skulle gjennomgå dramatiske forandringer, dels som direkte følge av internasjonal storpolitikk. Og Ellisif Wessel var merkbart til stede. Hun hadde et voldsomt følelsesmessig, praktisk og intellektuelt engasjement i skiftende saker.

Da storindustrien kom til Kirkenes, kastet hun seg inn i arbeidernes sak og stiftelsen av fagforeningen Nordens Klippe i 1907 , kjent for sin opprørske fane «Ned med tronen, alteret, pengevældet». Som ytterliggående sosialist hadde hun et påfallende stort kontaktnett, også i Russland, der hun hadde direkte kontakt med Lenin og hans hustru Nadesja Krupskaja. Ellisif Wessels våkne øyne og skarpe penn tiltrakk seg både oppmerksomhet og politisk overvåking.

Hennes liv skiftet mellom febrilsk aktivitet og total tilbaketrukkethet. Religiøse grublerier vekslet med aktiv ateisme. Hennes periode som fotograf, rundt århundreskiftet, især med skildringene av det førindustrielle Sør-Varanger, var også et uttrykk for et intenst engasjement i dokumentasjonen av et samfunn som forsvant.

Hun var ofte rart kledd, og hun hadde sterke meninger. Hennes mann Andreas, distriktslege, fylkeslege, ordfører, varamann til Stortinget etc., med vide vitenskapelige interesser, var hennes sindige motstykke. Han tok henne endog tilbake igjen etter separasjonen, som skyldtes hennes forhold til assistentlegen.

Det er ikke rart at det ble mange myter om denne damen. Mange har vanskelig latt seg etterprøve, bl.a. fordi nesten alt materiale i Kirkenes gikk tapt under den annen verdenskrig. F.eks. har myten om hennes sju døde barn trengt helt inn i Norsk biografisk leksikon (2005). Fru Wessel hadde problemer med å få barn. Da hennes eneste sønn døde 11 måneder gammel i 1892, sannsynligvis smittet med ektefellens tuberkulose, gikk hun inn i en dyp depresjon.

Forfatteren Steinar Wikan, som selv er fra Pasvik, følger Ellisif Wessel frem til hennes siste år på aldershjemmet i det utbombede Sør-Varanger. Han har gått grundig til verks i sine studier, fengslet av myter og virkelighet. Resultatet er blitt en meget god, veldokumentert biografi som ikke minst er ytterst leseverdig. Illustrasjoner, bibliografi og noteapparat har høy standard. Wikan beskriver fru Wessels liv, setter det i kontekst, drøfter mytene og punkterer mange av dem, slik at den virkelige Ellisif Wessel trer frem.

\section{Øivind Larsen}

Seksjon for medisinsk antropolog

og medisinsk historie

Universitetet i Oslo

\section{Gjennom mørket}

Enquist PO.

Ett annat liv

530 s. Stockholm: Norstedts, 2008. Pris SEK 299 ISBN 978-91-1-301893-5

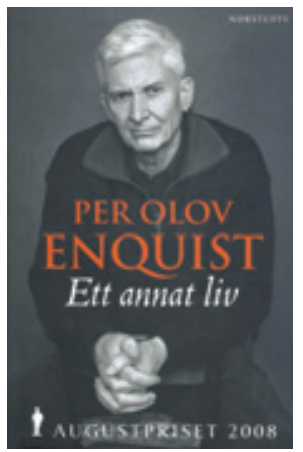

Motivet formuleres poetisk og kortfattet på baksiden av boken: «Han föds den 23 september 1934 i Hjogböle, en bondby i norra Västerbotten. Han lämnar sin by, blir författare, reser långt. Alt går så bra, sedan går det mycket illa. Den

6 februari 1990 börjar ett annat liv. Boken handlar om detta.»

Enquists bok om sitt liv frem til midten av 50-årsalderen har vakt stor oppmerksomhet i Sverige og er kommet i mange opplag. Den ble også raskt oversatt til norsk. Oppmerksomheten handler først og fremst om hvordan en av Nordens ledende forfattere havnet $i$ en ødeleggende alkoholisme som han, nesten som ved et under, kom seg ut av. Boken er tredelt, og det er den siste delen, «In i mörkret», som omhandler disse årene. Men også den mørkeste delen inneholder den humor som gjør at man hele tiden minnes om at alt liv har et janusansikt.

I bokens første del, «Oskuld», beskriver Enquist det pietistiske miljøet som har vært en forutsetning for flere av hans bøker. Deretter kommer den delen av hans liv vi kjenner gjennom bøkene og tallrike intervjuer, «En starkt upplyst plats». Det er en suksesshistorie, men man fornemmer hele tiden fortellerens mørkere sider, også fordi vi vet de vil ta over. Da han i 1969 fikk Nordisk Råds litteraturpris, var han den yngste prisvinner til da, bare 34 år gammel. I årene som fulgte kom romansuksessene, teaterstykkene, reisene. Han var blitt en offentlig figur. Dette var de årene da alt gikk så bra.

Så kom årene da det gikk «mycket illa». Det dramatiske er alkoholismen, erkjennelsen av at han med alkohol i blodet ikke kunne skrive noe som holdt. Den spiralaktige veien nedover. Men det som gjør mest inntrykk på denne leseren er behandlingsforsøkene, beretningene fra Stockholm og Island og muligens flere steder. Det ligger hen i alkoholtåken. Han rømmer og rømmer. Og som leser er det ikke vanskelig å forstå hvorfor, selv om det fører ham lenger ut og ned. Som ved et religiøst under begynner hans nye liv 6 . februar 1990; han vil noe annet med sitt liv enn å gå under. Enquist gir ingen sikker forklaring på hvorfor dette vendepunktet kom. Måneden før hadde alt vært verre enn noensinne.

Høsten 1991 kom Kapten Nemos bibliotek (1). Han kunne skrive igjen, men trodde dette skulle bli den siste romanen han skrev. Så feil kan man ta. Det var som om slusene ble åpnet, og $i$ årene som fulgte kom den ene romanen etter den andre, bl.a. den monumentale Lewis resa (2) om pinsebevegelsen i Sverige. Gud har sjelden vært langt borte i hans romaner, eller rettere, de gudfryktige har vært til stede omtrent hele tiden. Denne skrivebølgen har nå sist gitt oss beretningen om ham selv, en memoarbok i romans form. Det er et memoarverk og samtidig skjønnlitteratur, noe som ble bekreftet ved at den svenske forleggerforeningen ga ham Augustprisen i 2008 for årets svenske skjønnlitterære bok.

Det er i boken hele tiden en distanse. Enquist omtaler seg selv i tredjeperson, som «han». Boken blir fremragende ikke bare i kraft av hva han forteller - like stort inntrykk gjør det han ikke forteller. Den handler om et liv der mye går galt. Men også om et liv der mye lykkes. Og om at det igjen kan gå bra etter at alt har syntes håpløst. I det ligger det grunn til optimisme for oss alle.

\section{Per E. Børdahl}

Kvinneklinikken

Haukeland universitetssykehus

\section{Litteratur}

1. Enquist PO Kapten Nemos bibliotek Stockholm: Norstedts, 1991

2. Enquist PO. Lewis resa. Stockholm: Norstedts, 2001

\section{Gutane frå Voss...}

Lærum OD

I kastanjetreet

257 s, ill. Bergen: Vigmostad og Bjørke, 2008.

Pris NOK 349

ISBN 978-82-419-0501-8

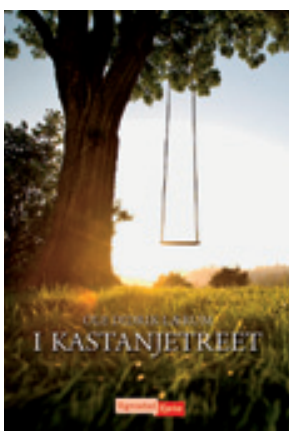

Patologen Ole Didrik Lærum er kjent for sitt omfattende og allsidige forfatterskap. Mange betrakter ham som en av legestandens (få) humorister, og man minnes humrende hans tidligere «originalartikkel» med spådommen om at glomeruluspodocyttenes fotprosesser en dag vil gå i utakt og danne en tumor - en 